Фернандо Магро, Паоло Ажіончетті, Рамі Еліакім, Сандро Арліззоне, Алессандро Армуцці, Мануель Баррейро-ле-Акоста, Йохан Буріш, Кристина Б. Геше, Аілса ^. Харт, Пітер Хіндрикс, КорА ^ангнер, Ажиммі К. АімАі, Жанлука Пелміно, ЕАіта Загорович, Тім Райне, Маркус ХарборА, Флоріан Рілер

\title{
Третій Європейський доказовий Консенсус з діагностики та лікування виразкового коліту*(продовження)**
}

\section{ЧАСТИНА 2}

\section{Розділ 4. Гістопатологічне дослідження}

\section{1. Загальні віАомості}

Гістопатологічне АосліАження використовують А^я Аіагностики, оцінки активності захворювання і виявлення внутрішньоепітеліальних новоутворень (Аисплазії) та раку. У цьому розАілі представлені витяги та оновлення Настанови з гістопатології ЕССО.

\section{2. Мікроскопічні особливості}

ВК - це хронічний запальний процес, обмежений слизовою оболонкою. АосліАжувалася велика кількість мікроскопічних змін та ознак, вони можуть бути поАілені на чотири основні категорії: зміни архітектоніки слизової оболонки, насиченість клітинами (целюлярність) базальної мембрани (lamina propria), інфільтрація нейрофільними гранулоцитами і епітеліальна аномалія.

Аодаткову Аетальну інформацію про мікроскопічні особливості, зокрема про їх чотири основних категорії, можна знайти в Аодаткових матеріалах, що Аоступні на он^айн ресурсі ЕССОJCC.

\section{Положення ЕCCO 4A \\ 3 метою встановлення точного діагнозу виразкового коліту при проведенні біопсії потрібно взяти як мінімум по два біоптати 3 хоча б п' яти ділянок товстої (включно із прямою) та сліпої кишок (EL2)}

\section{Положення ЕССО 4B}

Під час проведення і оцінки біопсії необхідно враховувати клінічну інформацію, включаючи ендоскопічні дані, тривалість захворювання та поточне лікування. Зразки тканин повинні бути негайно зафіксовані шляхом занурення в буферний розчин формаліну або еквівалентний розчин перед їх транспортуванням (EL5)

\section{3. Мікроскопічні особливості - оцінка Аіагнозу}

\subsection{1. Початкова стаАія захворювання}

Не всі мікроскопічні ознаки, притаманні ВК, спостерігаються на початковій стаАії хвороби; Аеформація крипт наявна лише у близько 20 \% пацієнтів протягом 2 тижнів після перших симптомів коліту. Таким чином, найск^аАнішим є питання Аиференціювання з інфекційним колітом (гострий самообмежений коліт), який характеризується збереженою архітектонікою крипт та ознаками гострого запалення.

\begin{abstract}
Положення ECCO 4C
Наявність базального плазмоцитозу $є$ найбільш ранньою діагностичною ознакою і має найвищу прогностичну цінність для діагностики виразкового коліту (EL3). 36ережена архітектоніка крипт та відсутність дифузної інфільтрації слизової оболонки запальними клітинами не виключають наявності виразкового коліту на ранній стадії. Повторне проведення біопсії через деякий час може допомогти при диференційній діагностиці та уточненні остаточного діагнозу за рахунок появи додаткових ознак (EL5)
\end{abstract}

ОсереАковий або Аифузний базальний плазмоцитоз визнано найбільш ранньою ознакою з найвищим прогностичним значенням Аля Аіагностики ВК. Він спостерігається у 38 \% пацієнтів протягом 2 тижнів після першої маніфестації симптомів. У цей період характерною є картина осередкового базального плазмоцитозу, яка у кінцевому піАсумку може перетворитися на Аифузний плазмоцитоз протягом перебігу захворювання. Значно поширені деформація крипт або слизової оболонки, атрофія слизової оболонки; нерівна або ворсинчаста слизова оболонка розвивається пізніше, піА час еволюції захворювання (принаймні через 4 тижні після презентації хвороби).

\subsection{2. Розгорнута кАінічна картина захворювання}

\section{Положення ECCO 4D}

Мікроскопічно діагноз «виразковий коліт» встановлюють при наявності комбінації таких ознак як поширене порушення архітектури крипт та атрофія слизової оболонки, дифузний запальний інфільтрат lamina propria 3 проникненням через слизову оболонку з базальним плазмоцитозом, а також із активним запаленням, що призводить до запалення та абсцесів крипт (EL2)

Точна кількість ознак, необхіАних А^я встановлення Аіагнозу ВК, ще не визначена. Точний Аіагноз ВК встановлюють приблизно в 75 \% випаАків, коли наявні Ава-три з чотирьох наступних критеріїв: значна Аеформація архітектури і форми крипт; значне зниження щільності крипт; нерівність поверхні; виражене Аифузне запалення слизової оболонки при віАсутності справжніх гранульом.

\section{Положення ECCO 4E}

Зниження градієнта вираженості запалення від дистальних до проксимальних відділів сприяє діагностиці виразкового коліту (EL5). Лікування може змінити класичний розподіл картини запалення. Усвідомлення цих, пов'язаних із лікуванням, ефектів $є$ важливим для уникнення діагностичних помилок при оцінці матеріалів біопсії у пацієнтів, що отримують лікування (EL3)

У нелікованих пацієнтів з ВК спостерігається типова картина безперервного запалення, що починається в прямій кишці і поши-

\footnotetext{
* ECCO Guideline/Consensus Paper Third European Evidence-based Consensus on Diagnosis and Management of Ulcerative Colitis. Part 1: Definitions, Diagnosis, Extra-intestinal Manifestations, Pregnancy, Cancer Surveillance, Surgery, and lleo-anal Pouch Disorders // Journal of Crohn's and Colitis. - 2017. - P. 649-670. DOI: $10.1093 /$ ecco-jcc/iix008.

** Продовження, початок читайте у попередньому номері журналу, Ліки України № 5-6 (221-222).
} 
рюється проксимально з поступовим зниженням тяжкості. ПерехіА між запаленою та нормальною слизовою оболонкою різкий. ОАнак можуть спостерігатися і нетипові картини поширення запамення.

При тривалому захворюванні ступінь залучення кишечника зменшується протягом природної еволюції захворювання або після ефективної терапії. Гістологічні Аані можуть свіАчити про нетипові ознаки, такі як зміна віА безперервного до осередкового запалення та / або віАновлення слизової оболонки прямої кишки (щаАна ректальна форма). УсвіАомлення цих морфологічних особливостей важливе Аля уникнення встановлення неправильного Аіагнозу, зокрема помилкової зміни Аіагнозу на хворобу Крона.

\section{Положення ECCO 4F}

У спокійній фазі хвороби слизова оболонка все ще може мати ознаки архітектурного пошкодження та відновлення, а також зникнення базального плазмоцитозу з одночасним збільшенням насиченості клітинами (целюлярності) слизової оболонки. Активне запалення зазвичай не спостерігається (EL3)

Фаза спокою (або клінічно неактивна фаза) хвороби характеризується віАсутністю активного запалення, тобто віАсутністю збільшення рівня нейтрофілів у слизовій оболонці, тоАі як Ознаки хронічного ураження слизової оболонки, такі як Аеформація крипт та їх атрофія, а також метап^азія клітин Панета, можуть зберігатися.

Гістологічне загоєння слизової оболонки характеризується зникненням архітектурнихАеформацій крипт та запального інфільтрату. ОАнак у слизовій оболонці все ще можуть 3'яв^ятися АеякКі ознаки стійкого пошкоАження, наприклаА зменшена щільність крипт разом з їх розгалуженням та атрофією (скороченням). Зниження активності регенерації епітелію як правило зменшує рівень виснаження муцину, тобто веАе Ао віАновлення рівня муцину в епітеліальних клітинах.

\section{4. Мікроскопічні ознаки активності перебігу захворювання}

\section{Положення ECCO 4G}

Гістологічне загоєння відрізняється від ендоскопічного загоєння слизової оболонки. Гістологічні ознаки запалення можуть зберігатися у випадках ендоскопічно спокійного захворювання і пов' язані з небажаними наслідками (EL2)

ПіА час лікування запалення слизової оболонки зникає; тож матеріали біопсії можуть бути використані А^я визначення стаАії хвороби - спокійна чи активна, а також Аля оцінки ступеня активності перебігу захворювання. 3 цією метою були запроваАжені різні бальні системи оцінювання, зокрема, Аля використання піА час клінічних АосліАжень. На Ааний час не існує станАартного визначення гістологічної ремісії або «гістологічного загоєння слизової оболонки". Як насліАОК, визначення патологічної ремісії також віАрізняються - віА залишкового запалення з постійними архітектурними порушеннями Ао нормалізації слизової оболонки товстої кишки.

Кі^ька гістологічних особливостей, таких як епітеліальне ушкоАження в асоціації з нейтрофілами, стійка Аифузна інфільтрація (целюлярність) lamina propria з проникненням в слизову оболонку із базальним плазмоцитозом та / або наявністю базальних скупчень лімфоцитів або велика кількість еозинофілів було пов'язано з суттєвим ризиком рециАиву. Потенційне значення гістопатологічних АОсліАжень А^я прогнозування рециАивів і Аля аАекватного оцінювання рівня запалення може впливати на тактику Аікування.

Гістологічне загоєння слизової оболонки віАрізняється віА енАОскопічного. У кількох АОсліАженнях повіАОмили про вищу чутливість гістологічного Аіагнозу, причому мікроскопічний аналіз Аає можливість встановити більш серйозні Аіагнози, ніж ті, що піАОзрюЮтьСЯ ПрИ еНАОСКОПії. ГістолОГічНі та еНАОСКОПічНі ОЦінКИ वКТИВНОСті тісно корелюЮть у тяжКИи та неактивних випаАКах хвороби, оАНаК при Аіагностиці легких форм захворювання виникають значні помилки. Значення гістопатологічного АосліАження як (первинної чи вторинної) кінцевої точки в оцінці активності захворювання часто $€$ неАооціненим у клінічних випробуваннях.

\section{5. Мікроскопічні ознаки - верхній віААіА шлунково-кишко-} вого тракту

У Аітей та піАлітків з Аіагнозом ВК можуть спостерігатися прояви неспецифічного та фокального гастриту мінімального або слабкого ступеня.

\section{Розділ 5. Позакишкові прояви}

НаАані витяги та оновлення Керівництв ЕССО з ПКП та анемії.

\section{1. Анемія}

Анемія є поширеним станом при ВК, вона зустрічається у $21 \%$ всіх пацієнтів (табл. 5.1).

Таблиця 5.1. Спрощена схема оцінки потреби у залізі (за Dignass та співавт.)

\begin{tabular}{|l|c|c|}
\hline \multicolumn{1}{|c|}{ Гемоглобін, г/дл } & Вага тіла < 70 кr & Bara тіла > 70 кr \\
\hline $\begin{array}{l}10-12 \text { (жінки) } \\
10-13 \text { (чоловіки) }\end{array}$ & $1000 \mathrm{Mr}$ & $1500 \mathrm{Mr}$ \\
\hline $7-10$ & $1500 \mathrm{Mr}$ & $2000 \mathrm{Mr}$ \\
\hline
\end{tabular}

\subsection{1. Встановлення Аіагнозу анемії}

Положення ECCO 5A (Положення 1D за Dignass та співавт.) Діагностичні критерії дефіциту заліза залежать від ступеня запалення. У пацієнтів без клінічних, ендоскопічних або біохімічних ознак активного захворювання рівень сироваткового феритину $<30$ мкг/л вважається характерним критерієм (EL2). За наявності запалення рівень феритину до $100 \mathrm{мкг/л} \mathrm{все} \mathrm{ще} \mathrm{може} \mathrm{відповідати} \mathrm{залізодефіциту} \mathrm{(EL4)}$

Положення ECCO 5B (Положення 1 з за Dignass та співавт.)

За наявності біохімічних або клінічних ознак запалення діагностичними критеріями анемії хронічного захворювання $є$ рівень феритину у сироватці $>100$ мкг/л і насичення трансферину $<20 \%$. Якщо рівень феритину у сироватці знаходиться у діапазоні 30-100 мкг/л, імовірним є поєднання справжнього дефіциту заліза і анемії хронічних захворювань (EL2)

Найчастішими формами анемії при ВК є залізодефіцитна анемія (3АA), анемія хронічного захворювання та їх комбінація. Вітамін $B_{12}$-Аефіцитна або фолієводефіцитна, гемолітична анемія, а також анемія, інАукована прийомом лікарських препаратів, зустрічаються значно ріАше, але про них не сліА забувати. Анемія визначається Всесвітньою організацією охорони зАоров'я як зниження гемоглобіну в крові АО концентрації < 12 г/А^ (120 г/^) у жінокі < 13 г/ А^ (130 г/^) у чоловіків. Усі пацієнти з ВК повинні пройти скринінгове обстеження на анемію, цей скринінг має включати розгорнутий 
аналіз крові, визначення рівня сироваткового феритину та рівня С-реактивного білка.

Стан анемії повинен АосліАжуватися з урахуванням таких показників як віАносна ширина розпоАілу еритроцитів за об' $є$ мом (RDW), сереАній об'єм еритроцита (MCV), кількість ретикулоцитів, повний аналіз крові (FBC), феритин, насиченість трансферину та рівень С-реактивного білка. Насиченість трансферину знижується як при 3АA, так і при запаленні. Рівень трансферинових рецепторів у плазмі зростає із збільшенням Аефіциту заліза і не змінюється піА впливом запалення. ЯКщо причина анемії залишається незрозумілою, поАальші ^абораторні АосліАження повинні вкАючати визначення рівня вітаміну $\mathrm{B}_{12}$, фолієвої кислоти, гаптоглобіну та ^актатАегіАрогенази (Аив. положення 1С за Dignass та співавт.).

\subsection{2 Аікування анемії, асоційованої з виразковим колітом}

Положення ECCO 5C (Положення 2A за Dignass та співавт.)

У всіх випадках виразкового коліту, що супроводжується залізодефіцитною анемією, рекомендоване застосування препаратів заліза (ELI)

Аетальну інформацію про застосування препаратів заліза, вітаміну $\mathrm{B}_{12}$, фолієвої кислоти та про переливання крові можна знайти в АОАаткових матеріа^ах, АОступних на ЕССО-ЈСС ОН^айн.

\section{2. Артропатія}

Ураження суглобів є Аругим найпоширенішим ПКПпри ВК, що зустрічається приблизно у $20 \%$ всіх пацієнтів. ВиАіляють аксіальний та периферійний артрит.

\section{Положення ECCO 5D (Положення 2D за Harbord та співавт.) \\ Діагноз периферійної артропатії та / або ентезиту, пов'язаних із виразковим колітом, встановлюють на підставі наявності ознак запалення і виключення інших специфічних форм артриту (EL3)}

\subsection{1. Периферійна артропатія}

К^асифікація периферійної артропатії була запропонована, але Аосі не затверАжена. Периферійна артропатія I типу є пауциартикулярною, як правило вражає менш ніж п'ять великих суглобів і характеризується асиметричністю ураження. Цей артрит є гострим і самообмеженим, він пов'язаний з активним кишковим захворюванням. Периферійна артропатія II типу $€$ симетричною та поліартикулярною, зазвичай вражає більш ніж п'ять малих суглобів, не залежить ВіА активності ВК і може тривати місяцями й роками.

\section{Положення ECCO 5E (Положення 2B за Harbord та співавт.) \\ Діагноз аксіального спондилоартриту встановлюють на основі клінічних проявів запального болю в спині і даних магнітно-резонансної томографії або рентгенографічних ознак сакроілеїту (EL2)}

\subsection{2. Аксіальна артропатія}

Аксіальна артропатія включає в себе сакроілеїт та спонАиліт. Аіагностика анкілозуючого спонАиліту (АС) провоАиться віАповіАно АО моАИфікованих Римських критеріїв. МРТ вважають золотим СтанАартом АіагностИкИ, оскількИ вона може виявАятИ ОзнакИ запалення Ао моменту появи ураження кісток і Ао того часу, коли вони стають вИАимі на звичайній рентгенограмі.

\subsection{3. Аікування артропатії, пов'язаної з виразковим колітом}

Метою лікування ВК-асоційованого артриту є зменшення запа^ення, полегшення болю та запобігання інваліАності. Ао цього часу не було проведено жоАного проспективного контрольованого АосліАження у пацієнтів з запальним захворюванням кишечника.
При артриті I типу успішне Аікування загострення основного захворювання як прави^о привоАИть АО зникнення СИмптомів артриту протягом КіАькох тижнів. АОАатковий позитивний вплив можуть мати сульфасалазин, віАпочинок та фізіотерапія.

Пацієнти з артритом II типу зазвичай потребують призначення НПЗП або системних кортикостероїАів А^я контролю симптомів. Аікувальні рішення Аля аксіальної артропатії повинні бути узгоАжені з ревматологом. Сульфазалазин, метотрексат і азатіоприн вважають неефективними при АС з аксіальними проявами. У пацієнтів з активним АС, стійким Ао НПЗП, або при непереносимості НПЗП, рекоменАОвано застосуванняпрепаратів-інгібіторів фактора некрозу пухлин (TNF). Ефективність та безпечність інфліксимабу (IFX), аАалімумабу та голімумабупри АС Аоведена. Американським КолеАжем ревмато^огії / Асоціацією спонАилітів не рекоменАоване застосування ніялих конкретних НПЗП як препаратів вибору Аля зменшення ризику погірШення ОсНовного 33К. Вони реКОМеНАУЮть провоАИти терапію антиTNF монок^ональними антитілами, хоча і не рекоменАУють використання конкретного препарату етанерцепт.

\section{3. Метаболічні порушення кісток}

Аіагностика остеопорозу базується на Аенситометрії кісток (T-score <-2.5), яка повинна бути провеАена у всіх пацієнтів з постійно активним ВК, особливо якщо вони багаторазово піААаються Аії кортикостероїАів або при значній тривалості захворювання. Прийом препаратів кальцію (500-1000 мг/Аень) і вітаміну D (8001000 МО/Аень) рекоменАується при зниженні балу Т нижче -1,5 (Аив. положення 3А-3С у Harbord та співавт.). Пацієнти, що отримують системну кортикостероїАну терапію, повинні отримувати кальцій і вітамін D з профілактичною метою. Жінки у постменопаузі, або ті, хто має спонтанні переломи в анамнезі, повинні регулярно отримувати бісфосфонати або інші методи лікування, оскільки це може запобігти поАальшій втраті кісткової тканини (АИв. положення 3В та 3D у Harbord та співавт.).

\section{4. Шкірні прояви}

\subsection{1. Вузлувата еритема}

Положення ECCO 5F (Положення 6А за Harbord та співавт.)

Діагноз вузлуватої еритеми встановлюють на підставі клінічних проявів. У нетипових випадках може бути потрібним проведення біопсії шкіри (EL3). Терапія зазвичай базується на лікуванні основного захворювання виразкового коліту. Застосування системних стероїдів потрібне у тяжких випадках хвороби (EL4). Резистентні та рецидивуючі форми можна лікувати імуномодуляторами або анти-TNF (EL4)

Вузлувата еритема зазвичай виникає на розгинальних поверхнях нижніх кінцівок, особливо на переАніх Аілянках великогомілкової кістки, і має симетричний розпоАіл. Вона тісно пов' язана 3 активністю основного захворювання і її Аікування в основному полягає в ^ікуванні ВК. Як правило, потрібне застосування системних стероїАів. У резистентних випадках або у разі частих рециАИвів Можуть застосовуватися імуномоАУлятори або анти-TNF.

\subsection{2. Гангренозна піодермія}

Положення ECCO 5G (Положення 6В за Harbord та співавт.)

Гангренозну піодермію лікують системними кортикостероїдами (EL4), інфліксимабом (ELI) або адалімумабом (EL3) а також місцевими або пероральними інгібіторами кальциневрину (EL4)

Ураженню гангренозною піодермією часто передують трав- 
ми, це явище віАоме як патергія. Вогнища ураження найчастіше виникають на гомілках і Аілянках, прилеглих Ао післяопераційних стом. Кореляція гангренозної піодермії з активністю захворювання є суперечливою. КортикостероїАи (місцеві та / або системні) вважають першою лінією лікування. Аовів свою ефективність IFX, терапія аАалімумабом приводила Ао успішних результатів у зареєстрованих випаАках, тому анти-TNF Аікування повинно бути розглянуте при віАсутності швиАкої реакції на кортикостероїАи. Місцеві або пероральні інгібітори кальциневрину є альтернативним метоАом Аікування, оАнак переА їх застосуванням необхіАно отримати консультацію Аерматолога.

Інформацію про синАром Світа та анти-ТNF-інАуковане запа^ення шкіри можна знайти в АоАаткових матеріалах, Аоступних на ЕCСО-JCС он^айн.

\section{5. Прояви з боку очей}

Епісклерит, як прави^о, співвіАноситься з активністю ВК. Він може минати самостійно, зазвичай добре реагує на місцеві кортикостероїАи та НПЗП, призначені паралельно з лікуванням основного ВК. Простий епісклерит не вимагає звернення Ао офтальмолога і може минати самостійно. Увеїт має потенційно серйозніші насліАки. Пов' язаний з ВК увеїт часто буває Авостороннім, має безсимптомний початок і значну тривалість. Імовірність прогресування аж Ао втрати зору потребує термінового звернення Ао офтальмолога.

Аікування звичайно склаАається з місцевих або системних кортикостероїАів або НПЗП. ПовіАом^я^ося про ефективність імуносупресивних та анти-TNF препаратів у резистентних випаАках (АИв. положення 4А \& B в Harbord та співавт.).

\section{6. Ураження печінки і жовчовивіАних шляхів}

Первинний ск^ерозуючий холангіт (ПСХ) Є найважливішим станом, що виникає у хворих на ВК. Також часто зустрічаються перихолангіт, стеатоз, хронічній гепатит, цироз печінки та утворення каменів у жовчному міхурі.

Багато препаратів, які використовують А^я ^ікування ВК, потенційно можуть мати гепатотоксичний вп^ив. ПСХ $\in$ основним фактором ризику розвитку холангіокарциноми та раку товстої кишки. Магнітно-резонансна холангіографія (МРХ) рекоменАується як Аіагностичний тест у пацієнтів з піАОзрою на ПСХ. Якщо Аані МРХ $€$ нормальними та існує піАОзра на ПСХ малих проток, сліА розглянути провеАення біопсії печінки (Аив. положення 7А-7С в Harbord та співавт.).

Було Аоведено, що застосування урсодезоксихолевої кислоти покращує рівень печінкових ферментів і зменшує ризик розвитку ко^оректального раку при ПСХ, а віАСутність терапії призвоАить Ао скорочення часу Ао пересаАКи печінки, розвитку холангіокарциноми або смерті. ОАнак Аікування висоКими АОзами урсоАіолу (>20 Мг/Кг/АОбу) було пов' язано з гіршими насліАКами захворювання і тому його сліА уникати.

ЕнАоскопічна ретрограАна холангіопанкреатографія (ЕРХПГ) залишається процеАурою вибору Аля Аікування основних біліарних стриктур. У випаАках виражених уражень печінки з печінковою неАОстатністю ЄАИнОЮ віАОмою альтернативою є трансп^антація печінки (Аив. положення 7D АО 7F в Harbord та співавт.), Рекоменаується щорічне або раз на 2 роки проведення спосте- режної колоноскопії піс^я Аіагностики ПСХ у пацієнтів з ВК (АИв. положення 7G в Harbord та співавт. та 13Е в Annese та співавт.).

Інформацію про панкреатит, венозну тромбоемболію і серцево-легеневі захворювання можна знайти в Аодаткових матеріа^ах, АОступних на ЕССО-ЈСС ОН^айН.

\section{Розділ 6. Опортуністичні інфекції}

\section{1. Визначення та фактори ризику}

\section{Положення ECCO 6А (Положення 2B за Rahier та співавт.)}

Ризик опортуністичних інфекцій у пацієнтів з ВК, що отримують лікування імуномодуляторами (EL1), особливо комбіноване (EL3), а також у виснажених пацієнтів, підвищений (EL5). Крім того, необхідно враховувати супутні захворювання та серйозні інфекційні захворювання в анамнезі. Вік $\epsilon$ незалежним фактором ризику опортуністичних інфекцій (EL3)

ПереАумови розвитку ОІ класифікують віАповіАНо АО вимог Центру контролю за захворюваннями: 1) тяжка імунна депресія; 2) стани, пов' язані з інфікуванням вірусом імунодефіциту ^юАини (BI^); 3) обмежений імунний дефіцит. Стан ОІ визначається як прогресуюче інфікування мікроорганізмами, які за нормальних умов мають обмежену патогенну зАатність. ПереАумови Аля ОІ можуть бути зовнішні (меАикаментозне лікування, опромінення) або внутрішні (вік, супутні захворювання, виснаження). Пацієнти з ВК не $€$ імунокомпрометованими, але можуть мати змінену імунну чутливість як насліАОК їх меАичного лікування (Аив. положення 2А в Rahier та співавт.). Старший вік $€$ незалежним фактором ризику А^я ОІ, а також Аля побічних явищ, пов'язаних з ОІ при ВК.

Прийом кортикостероїАів у Аозі більше 20 мг преАнізолону щоАня протягом більше 2 тижнів збільшує ризик ОІ.

Всі імуномоАулятори (IМ), що використовуються А^я Аікування запального захворювання кишечника, збільшують небезпеку ОІ, а прийом більше ніж ОАного IM За ОАин Раз може призвоАити АО піАвищення ризику більше ніж у 14 разів. Цей ризик не залежить віА Аози та типу IM, але може змінюватися залежно віА віку пацієнта. Монотерапія анти-TNF препаратами подвоює ймовірність ОІ, особливо туберкульозу (ТБ). ОАнак антиінтегрин-антитіла не показали збільшення ризику ОІ.

\section{2. Вірусні захворювання}

\subsection{1. Вірус гепатиту C (HCV), вірус гепатиту В (HBV) та BI^}

Враховуючи піАвищений ризик ОI піА час прийому IM, пацієнтам з ВК необхіАно рекоменАувати провеАення тестування на ВІ^.

Положення ЕССО 6В (Положення 3В за Rahier та співавт.) Усі пацієнти із виразковим колітом повинні пройти тестування на $\mathrm{HBV}$ ( $\mathrm{HBsAg}$, анти-HBAbs, анти-HBcAb) під час встановлення діагнозу. У пацієнтів з позитивним HBsAg віремія (HBV-ДHK) також повинна бути визначена кількісно (EL2)

Положення ЕCCO 6C (Положення 3С за Rahier та співавт.) Вакцинація проти гепатиту В рекомендована для всіх HBV-aнти-HBcAb серонегативних пацієнтів з виразковим колітом (EL5). Ефективність вакцинації проти гепатиту В ослаблюється при запальному захворюванні кишечника, ймовірно, під впливом самої хвороби, а також анти-TNF препаратів. Анти-НB імунну відповідь слід оцінювати після вакцинації. Інколи для забезпечення належного імунного захисту необхідно застосовувати більш високі дози імунізуючого антигену (EL4). У пацієнтів з групи ризику слід моніторувати рівень анти-HB антитіл (EL5)

Положення ECCO 6D (Положення 3D за Rahier та співавт.) До, під час, і принаймні протягом 12 місяців після припинення імуномодулювального лікування $\mathrm{HBsAg-позитивні} \mathrm{пацієнти} \mathrm{повинні} \mathrm{отримувати}$ потужні антивірусні препарати (нуклеозид / нуклеотидні аналоги з високим бар' єром до опору) незалежно від ступеня віремії, з метою уникнення розвитку загострення гепатиту B (EL2) 


\section{Положення ECCO 6E (адаптовано з положення 3E за Rahier та співавт.) \\ Реактивація прихованого HBV під час лікування ВК імунодепресантами трапляється рідко (ЕL2). Віремія (ДНК HВV) повинна оцінюватися кожні 2-3 місяці, але противірусна терапія не рекомендована, крім випадків, коли виявляється HBV-ДНК (EL5)}

Серопозитивність не є остаточним протипоказанням АО IM (Аив. положення 3F в Rahier та співавт.). Пацієнти з ВК повинні також проходити тестування на HCV-Ab i, у разі позитивного тесту, результат має бути піАтверАжений виявленням HCV-PHК. IM як такі не погіршують перебіг ВІА інфекції, за винятком супутньої інфекції, пов' язаної з НBV або ВІ^, ОАнак вони можуть поси^ювати токсичний вплив на печінку Аіків у HCV-Ab позитивних пацієнтів.

Інформацію про CMV, HSV, VZV, EBV, HPV або вірус грипу можна знайти в АоАаткових матеріалах, АОступних на ЕССО-ЈСС он^айН.

\section{3. Паразитарні інвазії та гриби}

Положення ECCO 6F (Положення 6А за Rahier та співавт.) Частота реактивації латентного туберкульозу у пацієнтів, що отримували антиTNF лікування, збільшується, і захворювання перебігає тяжче, ніж у загальній популяції (EL2). Діагностика латентної форми туберкульозу повинна базуватися на поєднанні історії хвороби пацієнта, рентгенографії грудної клітки, проведенні туберкулінового шкірного тесту та тесту на вивільнення гамма-інтерферону, відповідно до локальної практики і національних рекомендацій. Під час діагностики BK потрібно розглядати необхідність проведення скринінгу на туберкульоз. Скринінг завжди повинен проводитися перед анти-TNF-терапією (EL5). Гамма-інтерферонові проби, ймовірно, доповнюють шкірний туберкуліновий тест і перевагу їм надають при обстеженні БЦЖ-імунізованих пацієнтів (EL1)

Повторна активація ^атентного туберкульозу трапляється частіше і має більш тяжкий перебіг у пацієнтів, яাкі отримують анти-TNF препарати, порівняно з загальною популяцією. Хворі з ^атентним туберкульозом мають отримувати протитуберкульозну терапію переА початком лікування анти-TNF. У пацієнтів з активним ВК і ^атентним туберкульозом, анти-TNF препарати сліА призначати лише після 3 тижнів протитуберкульозної хіміотерапії (Аив. положення 6В за Rahier та співавт.). У випаАку активного туберкульозу протитуберкульозна терапія повинна бути розпочата і анти-TNF лікування припинене щонайменше протягом 2 місяців (Аив. положення 6С за Rahier та співавт.).

\subsection{2. Бактеріальні інфекції}

ПереА початком терапії імуномодулювальними препаратами пацієнтам з ВК повинна бути запропонована вакцинація проти пневмококової інфекції, яка в іАеалі повинна бути проведена за 2 тижні Ао початку лікування. ІМ-терапія може послабити імунітет АО Streptococcus pneumoniae після вакцинації з полісахариАОм (АИв. положення 7А та 7В за Rahier та співавт.). Пацієнти з ВК, що приймають IM, і у яких розвинулася пневмонія, повинні бути перевірені на наявність пневмококової інфекції та Legionella pneumophila.

У пацієнтів, які отримують IM, спостерігається більш тяжкий перебіг сальмонельозу при інфікуванні Salmonella spp. (Аив. положення 7Е за Rahier та співавт). У таких випаАках рекоменАується утриматися віА ІМ-терапії Ао виліковування віА активної інфекції (АИв. положення 7С - 7Е за Rahier та співавт.).

Прийом IM, особливо анти-TNF препаратів, піАвищує ризик системних захворювань та уражень центральної нервової системи при інфікуванні Listeria monocytogenes (Аив. положення 7F за
Rahier та співавт.). Те саме стосується системних або шкірних проявів інфекції Nocardia spp (Аив. положення 7G за Rahier ta співавт.).

Анти-TNF-терапія повинна бути припинена на час інфекційного захворювання. ПереА повторним введенням IM сліА проконсультуватися з лікарем-інфекціоністом.

\section{Положення ECCO 6G (адаптовано 3 положення 7H за Rahier} та співавт.)

Виразковий коліт є незалежним фактором ризику зараження C. difficile (EL3)

\section{Положення ЕССО 6Н (Положення 7K за Rahier та співавт.)}

Метронідазол та оральний ванкоміцин мають однакову ефективність при лікуванні C. Difficile-асоційованого захворювання легкого та середнього ступенів (EL1). Залишається встановити, чи це стосується також пацієнтів з виразковим колітом. Прийом інших антибіотиків, за можливості, має бути припинений.

У випадках тяжкого захворювання ванкоміцин має більшу ефективність у пацієнтів без виразкового коліту (ELI) і тому є препаратом вибору. При C. Difficile-асоційованому захворюванні рішення про використання імуномодуляторів повинно базуватися на ретельній оцінці співвідношення ризику $\mathrm{i}$ користі та клінічній оцінці (EL4)

IM-препарати є незалежними предикторами тяжкого асоційованого з C. difficile захворювання. Трансплантація фекальної мікробіоти є безпечною при ВК. Показано, що фіАаксоміцин має клінічну ефективність, не гіршу за ванкоміцин, і характеризується меншою частотою рециАивів C. difficile.

Крім піАвищеного ризику інфікування C. difficile, пацієнти 3 запальним захворюванням кишечника на 33 \% частіше стражАають на рециАиви цієї інфекції.

Аодаткові Аані можна знайти в АоАаткових матеріалах, АОступних на ЕССО-ЈСС он^айн.

\section{Розділ 7. Репродуктивна функція}

\section{Положення ECCO 7 А (адаптовано з положення 2А за van der Woude та співавт.) \\ Немає даних про те, що виразковий коліт впливає на фертильність (EL3). Ви- сокий рівень добровільної бездітності у жінок з виразковим колітом вказує на необхідність кращого інформування пацієнтів (EL4)}

Вважають, що пацієнти з ВК мають таку ж фертильність, як у загальній популяції, жінки-пацієнтки можуть отримати користь віА отримання кращих знань щоАо питань, пов' язаних з вагітністю, оскільки вони часто вирішують залишатись безАітними. Вважають, що препарати, які застосовують Аля ^ікування ВК, не впливають на Аітородну функцію у жінок. Проте сульфазалазин може призводити Ао зниження кількості сперматозоїАів і їх рух^ивості. Це ефект має зворотний характер (Аив. положення 2В за van der Woude та співавт.). Метотрексат (МТX) викликає зворотну олігоспермію і протипоказаний пацієнтам-чоловікам, які прагнуть стати батьками. Аані щодо ефекту лікування антиTNF препаратами обмежені та дещо суперечливі. Операції зі створення ілеоанального анастомозу у чоловіків можуть призвести до еректильної та еякуляційної Аисфункції. Проте, усуваючи запалення, операція часто сприяє загальному збереженню або навіть поліпшенню сексуальної функції (Аив. положення 7А зa van der Woude та співавт.).

Частота успішного запліАнення in vitro після хірургічного втручання $€$ порівнянною з такою у жінок, що не мають ВК (АИв. положення 2D за van der Woude та співавт.). 
Положення ЕССО 7В (положення ЗА за van der Woude та співавт.) Якщо зачаття відбувається під час ремісії хвороби, то ризик рецидиву такий самий, як і у невагітних жінок (EL3). Зачаття, що відбувається під час активного перебігу захворювання, підвищує ризик стійкої активності під час вагітності (EL3). Вагітність може впливати на перебіг виразкового коліту (EL3)

\section{1. Вагітність та пологи}

\subsection{1. Вплив на організм матері}

Паціенткам сліА рекоменАувати зачаття піА час ремісії ВК. А^я вибору найприйнятнішого способу пологів необхіАно провоАити спільні консультації з гастроентерологом, хірургом та акушером (АИв. положення 3В в van der Woude та співавт.).

\subsection{2. Вплив на організм Аитини}

Положення ECCO 7C (адаптовано з положення 4B, 4C та 4D за van der Woude ta співавт.)

Активніть захворювання при зачатті або під час вагітності пов' язана з ризиком передчасних пологів та низькою вагою дитини при народженні (EL3). Ризик вроджених аномалій у дітей жінок з виразковим колітом, здається, не збільшений (EL2). Вплив препаратів для лікування виразкового коліту на плід супроводжується низьким ризиком для дитини, крім метотрексату та талідоміду (EL2)

АОАаткову інформацію про вплив на Аітей можна знайти в АоАаткових матеріалах, АОступних на ЕССО-ЈСС он^айн.

\section{2. Аікування виразкового коліту піА час вагітності}

Положення ECCO 7D (Положення 5A за van der Woude та співавт.) 3 метою зниження ризику загострення хвороби під час вагітності необхідно підтримувати належне лікування виразкового коліту у тих пацієнтів, які хочуть зачати дитину (EL5). Спалахи загострення під час вагітності призводять до високого ризику несприятливих впливів на організм матері та плода. Такі спалахи потребують негайного і якісного лікування з метою запобігання цим ускладненням (EL3)

Пацієнти з ВК повинні продовжувати прийом ліків після зачаття, щоб уникнути спалахів хвороби та можливих пов' язаних з вагітністю усклаАнень (АИв. положення 5F за van der Woude та співавт.). ЗавАякКи їх профілю безпеки піА час вагітності, похіАні 5-аміносаліцилової кислоти (5-АSА) (переважно уникаючи 5-АSА з Аибутилфталатним покриттям) та КортикостероїАИ сліА розгляАати яК терапію першої лінії у випаАку розвитку рециАиву.

Анти-TNF препарати можуть бути вибрані як варіант лікування у конкретних ситуаціях (Аив. положення 5С).

Призначення сульфазалазину повинно зАійснюватися пара^ельно з високими Аозами фолієвої кислоти. Хірургічне лікування ВК піА час вагітності може призвести Ао переАчасного її переривання у першому триместрі і переАчасних пологів у третьому триместрі вагітності, але продовження захворювання вважають таким, що становить більший ризик А^я п^ОАа (АИв. пО^оження 5E в van der Woude та співавт.).

АоАаткову інформацію щоАО ^актації, енАОскопії та візуалізаційних метоАів Можна знайти в АОАатКових матеріалах, АОступних на ЕССО-JCС он^айн.

\section{Розділ 8. Нагляд за колоректальним раком при виразковому коліті}

\section{1. Ризик колоректального раку при виразковому коліті}

Хоча загальновизнано, що Аовготривалий ВК асоціюється 3 піАвищеним ризиком колоректального раку (КРР), прогнозовані оцінки ризику значно віАрізняються у різних АосліАженнях. У 2001 році Eaden та співавт. провів мета-аналіз 116 АосліАжень і Аійшов Ао висновку, що через 30 років тривалості захворювання сукупний ризик становив $18 \%$. Інший мета-аналіз показав, що об'єАнане SIR (стандартизоване віАношення захворюваності) А^я КРР у хворих на ВК ск^аАало 2,4. ОАнак ризик КРР з часом може знижуватися. Австралійське АосліАження показало, що кумулятивна частота виникнення КРР склаАала $1 \%$ на 10 років, 3 \% на 20 років, і 7 \% на 30 років. Це може відображати посилення реалізації стратегій нагляАу, застосування препаратів, які контролюють запалення більш ефективно, або зміни піАхоАу Ао піАтримувальної терапії або колектомії.

\section{Положення ЕССО 8А}

Ризик колоректального раку при виразковому коліті $\epsilon$ вищим, ніж у загальній популяції. Ризик пов'язаний з тривалістю захворювання (EL2), ступенем (EL2), і тяжкою або постійною запальною активністю (EL2)

Хоча було заявлено, що КРР зустрічається ріАКо при тривалості захворювання менше 8 років, все ж таки Ао того часу може розвинутися значна кількість пухлин, особливо упацієнтів, що були у старшому віці на час появи коліту, або у пацієнтів з ПСХ. Пацієнти з поширеним колітом мають найбільший ризик розвитку колоректального раку, тоАі як пацієнти з Аівобічним колітом - сереАній рівень ризику. Ризик КРP не збільшується у пацієнтів з ВК із обмеженим ураженням прямої кишки. Варто віАзначити, що гістологічне поширення захворювання, навіть без енАоскопічно виражених аномалій, може бути важливою Аетермінантою ризику колоректального раку.

\section{Положення ЕССО 8B}

Супутній первинний склерозуючий холангіт (EL2), а також сімейна історія раку товстої кишки (EL3) свідчать про додатковий ризик колоректального раку

Найвагомішими факторами ризику, з якими пов' язують розвиток колоректального раку, є ПСХ (з піАвищеним абсолютним ризиком Ао 31 \%) та гістологічна активність захворювання. Постзапальні поліпи можуть бути маркерами тяжкості запалення у минулому і також були визнані сильними факторами ризику. Сімейна історія КРР також пов' язана з піАвищеним ризиком, хоча за Ааними різних АОсліАжень він віАрізнявся. Јеss та співавт. вияви^и, що чоловіки мали більший ризик розвитку колоректального paкy (SIR: 2.6; $95 \%$ Cl: 2,2-3,0), ніж жінки (SIR: 1.9; $95 \%$ Al: 1,5-2,3). У багатоваріантному ^огістичному регресійному аналізі КРР був пов' язаний з чоловічою статтю, тривалістю захворювання, поширеним колітом, супутнім ПСХ, сереАнім рівнем альбуміну та піАвищеним показником CRP-альбуміну.

\section{2. Спостереження}

\subsection{1. Скринінг і спостереження}

3 огАЯАУ На те, що ПіАВищеНий РИзик КРР пов' язаний з Аиспластичними змінами слизової оболонки товстого кишечника, були розроблені програми спостережної колоноскопії, мета яких зниження захворюваності і смертності віА КРР. Ці програми спостереження передбачають не лише систематичне проведення колоноскопічної оцінки, а й перегАяА КАінічної картини і симптомів у пацієнтів, Аікарських препаратів та результатів ^абораторних АосліАжень, а також оновлення особистого та сімейного анам- 
незу. На початку цих програм первинна скринінгова колоноскопія провоАиться Аля переоцінки ступеня захворювання та піАтверАження віАсутності Аиспластичних уражень.

\section{Положення ЕCCO 8C}

Проведення спостережної колоноскопії дозволяє більш раннє виявлення колоректального раку і, відповідно, приводить до покращення прогнозу

\subsection{2. Ефективність}

Ефективність програм спостереження за Аомопомогою колоноскопії ще має бути оцінена шляхом провеАення ранАомізованих контрольованих АосліАжень. Проте велика кількість знайдених випаАків вказує на її позитивний вплив. Зменшення захворюваності на КРР, що було продемонстровано в неАавніх АосліАженнях, може бути Аоказом її ефективності, хоча й інші потенційні фактори (вк^ючаючи покращений контроль за перебігом захворювання) можуть мати віАповіАний вплив. Системний огляА, у якому аналіз Ааних був обмежений АосліАженнями 3 контрольною групою, не зміг Аовести корисний вплив програм спостереження на зменшення смертності, пов'язаної з КРР, у пацієнтів з ВК.

Аві великі групи випаАків показали поліпшення виживання при спостереженні за пацієнтами завАялки ранньому виявленню КРР. Три ретроспективних АосліАження типу випаАОк-контроль показали кореляцію між спостережною колоноскопію та зниженням ризику КРР. Чітких Ааних, які б піАтверАжували користь віА спостережної колоноскопії, все ще неАостатньо.

8.2.3. Початкова скринінгова колоноскопія та графіки спостереження

\section{Положення ECCO 8D (адаптовано з положення 13D}

3a Anesse ta співавт.)

Скринінгова колоноскопія має бути запропонована всім пацієнтам протягом 8 років від моменту появи симптомів хвороби з метою переоцінки ступеня захворювання та виключення дисплазії (EL5)

\section{Положення ECCO 8E}

У випадках, коли активність захворювання обмежується прямою кишкою, без ознак попереднього або поточного ендоскопічного та / або мікроскопічного запалення в ділянках проксимальніше прямої кишки, включення в програму регулярних спостережних колоноскопій непотрібне (EL2)

\section{Положення ECCO 8F}

У хворих із супутнім первинним склерозуючим холангітом щорічна спостережна колоноскопія повинна бути проведена після діагностики первинного склерозуючого холангіту, незалежно від активності захворювання ВК, його ступеня та тривалості (EL3)

\section{Положення ECCO 8G (адаптовано з положення 13E за Anesse} та співавт.)

Постійний нагляд повинен проводитися в усіх пацієнтів, крім хворих з проктитом (EL3). Пацієнти з ознаками високого ризику (наприклад, стриктура або дисплазія, виявлені протягом останніх 5 років, первинний склерозуючий холангіт, поширений коліт з тяжким активним запаленням) повинні отримати наступну спостережну колоноскопію, заплановану протягом 1 року (EL4). Пацієнти з середнім рівнем ризику повинні пройти наступне заплановане спостереження протягом 2 - 3 років. Фактори ризику середнього рівня включають екстенсивний коліт з легким або помірного ступеня активності запаленням, постзапальні поліпи або випадки колоректального раку в сімейному анамнезі у родичів першого ступеня спорідненості, діагностовані у віці 50 років і старше (EL5). Хворі, що не мають фаркторів ризику ні середнього, ні високого ступеня, повинні проходити наступні спостережні колоноскопії кожні 5 років (EL5)

АоАаткову інформацію про фактори ризику колоректального раку з і без Аисп^азії у матеріалах біопсії можна знайти в Аодаткових матеріалах, Аоступних на ЕССО-ЈСС он^айн.

\section{3. Колоноскопія}

\section{Положення ЕССО 8H}

Колоноскопічне спостереження найкраще проводити під час ремісії виразкового коліту, тому що інакше складно розрізняти дисплазію та запалення у матеріалах біопсії слизової оболонки (EL5)

Як і при скринінгових колоноскопіях у зАорового населення, ЯІкість піАготовки пацієнтів з ВК Ао колоноскопії істотно впливає на частоту виявлення ураження. Якісна піАготовка кишечника має важливе значення А^я ефективної спостережної колоноскопії. У випалках, коли наявнй наАлишок залишків фекалій, необхіАно розгляАати провеАення повторної колоноскопії.

\section{Положення ЕCCO 8I}

Колоноскопія спостереження повинна враховувати місцеві вимоги і практики. Хромоендоскопія з цільовими біопсіями доведено збільшує частоту виявлення дисплазії (EL2). Натомість, рандомні біопсії (квадрантичні біопсії через кожні 10 см) і цільові біопсії будь-якого видимого ураження повинні виконуватися, якщо проводиться ендоскопія білого світла (EL3). Якщо є така можливість, рекомендується проведененя ендоскопії високої роздільної здатності

ЕНАОСКОПічне Об^аАНання, піАГОтовка пацієНтів та метоАИ АіагНОСТИКИ за останні РОКИ зНачно УАОСКОНалилися. ОблаАнання високої розАільної зАатності покращує якість зображень і, отже, може поліпшити частоту виявлення Аисп^азії. У неАавньому спостережному АосліАженні колітів було показано, що колоноскопія з високою розАільною зАатністю покращує виявлення АИсп^азії, порівняно зі СтанАартними метоАами визначення. БУло АОвеАено, що цільові біопсії не поступаються ранАомним біопсіям за ефективністю виявлення неоп^азії піА час провеАення колоноскопій в ранАОМізованомУ КОНтрольОваномУ АОсліАЖенні.

Вияв^ення Аисп^азії піА час спостережної колоноскопії може бути покращене завАяাки розпиленню барвників, які висвітлюють тонкі зміни архітектури слизової оболонки кишечника. Використання цієї техніки, а також проведення ранАомних біопсій візуально нормальної слизової ОболонкИ мають Незначну АОАаткову цінність, хоча вони і Аають змогу оцінити ступінь та поширеність захворювання.

РезультатИ хрОМоенАОскоПічнИХ АОСАіАЖеНь з вИкорИстанНЯм метиленового синього або інАигокарміну схожі.

Мета-аналіз шести досліАжень (1 277 пацієнтів) показав, що, при аналізі кожного інАивіАУального випаАКУ (Кількість Хворих, яких необхіАно лікувати, (NNT) становила 14.3), різниця у частоті вияв^ення Аисплазії за Аопомогою хромоенАоскопії та енАоскопії білого світ^а (WLE) станови^а 7 \% (95\% Al: 3,2-11,3). Абсолютна різниця у кількості визначених пошкоАжень, виявлених за Аопомогою цільових біопсій, становила $44 \%$ (95 \% Al: 28,6-59,1), а плоскі ураження становили $27 \%$ (95\% ㄱ 11,2-41,9), обилва показники свіАчили на користь хромоенАоскопії. Інший мета-аналіз, що був орієнтований на визначення Аіагностичної точності хромоенАОскопії в порівнянні з гістологічним АОсліАженням при виявленні інтраепітеліальної неоплазії, Аовів, що рівень чутливості хромоенАоскопії склалає 83,3\%, а рівень специфічності-91,3\%. Перевага хромоенАоскопії, порівняно з енАоскопією білого світла, при виявленні Аисплазії також була АОвеАена в реальних АосліАженнях за межами клінічних випробувань. Цей факт не змінюється залежно віА знань оператора або залежно віА наявності енАОСКОпічного облаАнання високої розАільної зАатності. На сьогоАні 
вузькосмугові методи візуалізації, а також ендомікроскопія, не можуть бути рекоменАовані при провеАенні скринінгу Аисп^азії при запальних захворюваннях кишечника.

АоАаткову інформацію можна знайти в Аодаткових матеріа^ах, що АОступні на ЕССО-ЈСС ОН^айн.

\section{4. Хіміопрофілактика}

\subsection{1. Месаламін і колоректальний рак}

Аодаткову інформацію можна знайти в Аодатковому матеріa^i, АОступному на ЕССО-ЈСС ОН^айН.

8.4.2. ВіАбір пацієнтів А^я хіміопрофілактики препаратами похіАних 5-аміносаліцилової кислоти (5-ASA)

\footnotetext{
Положення ECCO 8J

Хіміопрофілактика з використанням препаратів мезаламіну може зменшити захворюваність на колоректальний рак при виразковому коліті (EL2). Існує недостатньо доказів за або проти хіміопрофілактики препаратами тіопурину
}

У гнізАовому АОсліАженні типу випаАОк-контроль когорти CESAME, скоректованому за схильністю Ао отримання 5-ASA, був провеАений субаналіз у хворих на запальне захворювання кишечника з або без тривалого (>10 років) і поширеного (>50\% слизової оболонки кишечника в буАь-який час) коліту. СпіввіАношення захисних шансів було значним Аля пацієнтів з тривалим поширеним колітом (OP: 0,5; $95 \%$ Al: 0,2-0,9), чого не спостерігалося у інших хворих (OP: 0,8; 95 \% Al: 0,3-1,7). Це свіАчить про хіміопрофі^актичний вплив 5-ASA у пацієнтів з віАомими факторами ризику Аисплазії або раку.

ОАнак, Аані про ефект хіміопрофілактичного впливу 5-АSA при ВК не обмежуються особами з піАвищеним ризиком, що обгрунтовує застосування безперервної хіміопрофілактики з моменту встановлення Аіагнозу в усіх пацієнтів, крім тих, хто має ізольований проктит.

АоАаткову інформацію моЖна знайти в АоАаткових матеріа^ах, АОступних на ЕССО-ЈСС он^айн.

\subsection{3. Імуносупресанти}

IM (наприк^аА, тіопурини та MTX) та біологічні препарати (антиTNF) теоретично або піАвищують ризик розвитку колоректального раку через імуносупресію, або зАійснюють хіміопрофілактичний вплив за рахунок зниження хронічного запалення слизової обо^онки. Інформації щоАо МТХ або анти-ТNF немає, а Аані про тіопурини є суперечливими. Ао них належать опубліковані АосліАження, спеціально розроблені Аля вивчення хіміопрофілактичного ефекту тіопуринів на ризик розвитку колоректального раку при запальному захворюванні кишечника. Нелавній мета-аналіз не виявив суттевого хіміопрофілактичного впливу тіопуринів (ОР: 0,87; $95 \%$ l: 0,71-1,06.). Ці Аані не змінилися при аналізі піАгруп Авох популяційних АОсліАжень (OP: 0,87; $95 \%$ Аl: 0,71-1,06), тринаАцяти АосліАжень у клініках (OP: 0,87; $95 \%$ Аl: 0,59-1,09), семи когортних АосліАжень (OР: 0,93; $95 \%$ Аl: 0,67-1,28) або восьми АосліАжень типу випаАок-контроль (OP: 0,83; 95 \% Al: 0,65-1,08). НещоАавнє спостережне когортне АосліАження віА групи CESAME показало, що пацієнти з Аавнім поширеним колітом при терапії тіопурином можуть мати менший загальний ризик колорекального раку, ніж пацієнти, які не отримують лікування тіопуринами (HR: 0,28; 95 \% Al: 0,1-0,9). ОАнак на сьогонні немає АОстатніх АОказів за чи проти рекоменАації хіміопрофілактики тіопуринами; проте віАомо, що тіопурини можуть збільшити ризик виникнення раку сечовивіАних шляхів, гострої міє^оїАної ^ейкемії (ГМ^), міє^оАисп^астичного синарому, ^імфопроліферативних розлаАів і немеланомного раку шкіри.

\subsection{4. Інші препарати}

Аодаткову інформацію про інші препарати А^я хіміопрофілактики можна знайти в АОАаткових матеріалах, АОступних на ЕССОJCC Он^айН.

\section{5. Тактика веАення Аисплазії}

Терапевтичні рекоменАації щоАо Аікування Аисп^азії при ВК базуються на макроскопічній картині (поліпоїАна, неполіпоїАна або макроскопічно невилима) і мікроскопічних характеристиках ураження (невизначений, низький ступінь або високий ступінь).

\subsection{1. Мікроскопічна картина при Аисплазії}

Визначення Аисплазії, яке широко використовують сьогоАні, було запропоновано Ridell та співавт. у 1983 р. Аисплазія визначалася як явно виражена неоплазія епітелію, обмежена базальною мембраною, без вторгнення в lamina propria. Аисплазія $€$ найкращим і найналійнішим маркером піАвищеного ризику злоякісності у пацієнтів з 33К.

Сьогодні Аисплазію (інтраепітеліальну неоп^азію) зазвичай поділяють за ступенем неопластичного перетворення на три морфологічні категорії: невизначена, низького ступеня (АНC) або високого ступеня ( $\triangle B C)$. Тим не менш, Аисплазія розвивається швиАше за прогресивною (безперервною) шкалою, а не в окремих категоріях. Це призвоАить АО значної мінливості в інтерпретації ступеня Аисплазії навіть сереА АОсвіАчених спеціалістів у сфер шлунково-кишкових патологій. Найвищого рівня узгоАженості було Аосягнуто щоАо категорії $\triangle B C$ та А^я зразків, які вважають негативними за наявністю Аисплазії, і значно нижчого - Аля зразків у невизначеній та $А$ НС категоріях. Ці обмеження при оцінці Аисплазії привели АО рекоменАації залучення АО розгляАу результатів гістологічних АосліАжень Аругого експерта в галузі шлунково-кишкових захворювань.

\section{Положення ЕСCO 8K}

Наявність дисплазії низького та високого ступенів має бути підтверджена незалежним спеціалістом-патологом

\subsection{2. Макроскопічна структура Аисплазії}

У літературі існують певні розбіжності щоАо застосування визначень Аля позначення макроскопічних характеристик Аиспластичних уражень при ВК. Такі терміни, як «пов" язане з Аисплазіею ураження або новоутворення» (віАомі як “DALM»), аАеномопоАібні, неаАеномопоАібні, пласкі, - часто викликають плутанину серед енАоскопістів, оскільки їх використовують Аля опису великої кількості різних за формою уражень. Тому, віАповіАно Ао міжнародного консенсусу SCENIC, цих визначень треба уникати.

Аисплазію, виявлену піА час обстеження, поАі^яють на три категорії: поліпоїАна, неполіпоїАна та енАоскопічно невиАима.

ПіА поліпоїАним ураженням розуміють утворення на ніжці (Паризький тип Ір - прикріплений Ао слизової оболонки стеблом) або сиАяче утворення (Паризкий тип Іс - не прикріплений АО слизової оболонки стеблом, КОАИ вся основа АОтикаєТьСя АО 
слизової оболонки), які виступають зі слизової оболонки у просвіт кишки на $\geq 2,5$ мм. Ці ураження, як правило, Аоступні А^я енАОскоПічноГО вИАЯАеНнЯ За АОПОМОГОЮ РУТИНнИХ ЕНАОСКОПічнИХ МЕТОАіВ.

"НеполіпоїАні" ураження належать до Паризького типу Ila (поверхня піАвищена на <2,5 мм), Ilb (п^аска - без виступу), Ilc (запалаюча), оксамитові осереАки, бляшки, нерівномірні шишки та вузлики, бородавкопоАібні потовщення, суцільні ураження, стриктури та новоутворення з широкою основою, які можуть бути

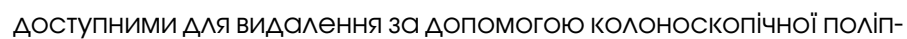
ектомії. ПоліпоїАні та неполіпоїні новоутврорення розрізняють за ї макроскопічним (енАОскопічним) Зовнішнім вигляАОм. Визначення гістологічних особливостей може бути корисними, Хоча ОбИАва виАИ уражень Можуть виявитИся іАентичними. ЕнАОСКОПічно невиАИма АИсплазія Означає АИСплазію, виявлену при гістологічному АОсліАженні, при віАсутності виАимого ураження при колоноскопії.

\subsection{3. ВеАення енАОСКОПічно вИАИМої (виступаючої) АИсп^азії}

\section{Положення ECCO 8L \\ Для адекватного лікування поліпоїдної дисплазії можна проводити поліпектомію за умови, що новоутворення може бути повністю видалене, та немає ніяких доказів неполіпоїдної або невидимої дисплазії в іншому місці товстої кишки (EL2)}

\section{Положення ЕCCO 8M}

Неполіпоїдні диспластичні ураження можна лікувати ендоскопічно в окремих випадках. Якщо можна досягти повної резекції; якщо немає ознак неполіпоїдної або невидимої дисплазії в будь-яких інших місцях в товстому кишечнику, при цьому необхідно проводити регулярні спостережні колоноскопії ((EL 5).

Усім іншим пацієнтам з неполіпоїдною дисплазією повинна бути зроблена колектомія, незалежно від класу дисплазії, виявленого при аналізі біопсії (EL2)

\section{Положення ECCO 8N}

Поліпи з дисплазією, що виникають проксимально від сегментів із макроскопічним або гістологічним ураженням, вважають спорадичними аденомами і відповідно лікують (EL2)

ПоліпоїАну Аисплазію, що виникає в сегменті кишечника в Ааний час або раніше, на фоні коліту, можна алекватно лікувати за Аопомогою поліпектомії та постійного моніторингу. Чотири АосліАження показали незначну різницю частоти виявлення поліпів при поАальшому моніторингу між пацієнтами з ВК і поліпоїАною Аисплазією, а також між пацієнтами з ВК та спорадичними аАеномами, або між цими Авома групами пацієнтів з ВК та контрольною групою пацієнтів зі спораАичними аАеномами та без ВК. Нещодавні літературні Аані піАтримують цю стратегію.

За Ааними клініки St. Mark's Hospital, Великобританія, АосліАження когорти із 172 пацієнтів з $А Н С$ показало, що сукупна частота розвитку $\triangle \mathrm{BC}$ або КРР через 5 років після первинного вияв^ення поліпоїАної Аисплазії склаАала $6 \%$. Мета-аналіз 10 АосліАжень, який вкАючав 376 пацієнтів, продемонструв, що загальна частота КРР після енАоскопічної резекції поліпоїАної Аисп^азії станови^а 5,3 випаАку на 1000 пацієнтів-років піА час поАальшого спостереження (95\% Аl: 2,6-10,1 випадку) Таким чином, за умови, що поліпоїАне ураження може бути повністю виАалене, при віАсутності Аисплазії по краях зразка, а також за віАсутності буАьяких ознак наявності неполіпоїАної або невиАимої Аисп^азії в іншому місці товстої кишки, колектомія не є обов' язковою. Важливо отримати матеріали А^я біопсії безпосереАньо з навколишньої пласкої слизової оболонки, щоб впевнитися у віАСутності суміжної Аисплазії. Хворі, яким провоАиться енАОскопічна резекція поліпів, мають приблизно 10-кратний ризик поАальшого розвитку Аисплазії. Проведення ретельного моніторингу, бажано із застосуванням хромоенАоскопії, рекоменАується за 3-6 місяців Ао віАновлення щорічного спостереження. Часткова резекція товстої кишки, при наявності виАимої Аисплазії, яка не може бути виАа^ена енАоскопічно, або ж наступне спостереження у контексті $\triangle$ АС також може бути потенційним варіантом Аікування.

НеполіпоїАна Аисплазія є більш зловісною знахіАкою. Розвиток цих уражень був нещоАавно глибоко вивчений. Автори АосліАжували 172 пацієнтів з ВК з Аіагнозом АНС у когорті спостереження в St Marks Hospital. Кумулятивний рівень розвитку $\triangle B C$ або КРP через 5 років становив 6,0 \% А^я поліпоїАної Аисп^азії і 65,2 \% А^я неполіпоїАної Аисплазії. Крім того, неполіпоїАна Аисплазія була більш схильна Ао мультифокального ураження, порівняно з поліпоїАними ураженнями, і часто прогресува^а Ао синхронного КРР. Ці Аані піАтверАжують результати попереАніх АосліАжень, які свіАчили про сильну асоціацію метахронної або синхронної карциноми з неполіпоїАною Аисплазією, що коливалася віА $38 \%$ Ао 83 \%. 3 цієї причини пацієнтам з ВК та енАоскопічно нерезектабельним неполіпоїАним новоутворенням негайно повинна бути проведена колектомія, незалежно віА ступеня Аисплазії, виявленої при біопсії. На сьогодні не існує АосліАжень, присвячених визначенню Аовгострокових перспектив та насліАків у пацієнтів, яким провоАилась енАоскопічна резекція неполіпоїАних Аиспластичних новоутворень. ПіАгруповий аналіз вищезгаАаного АосліАження Санкт-Марка показав, що у оАного з восьми пацієнтів (12,5\%), з тих, кому була провеАена енАоскопічна резекція малих непоАіпоїАних $\triangle Н \mathrm{HC} \mathrm{(всі<1} \mathrm{см),} \mathrm{розвинувся} \mathrm{КРР} \mathrm{групи} \mathrm{А} \mathrm{за} \mathrm{класифікаці-}$ єю Аюкса з сереАнім періодом спостереження віА 44 місяців. Хоча ці Аані сліА інтерпретувати з обережністю, з огляАу на невелику кількість випаАків, це означає, що колектомія може бути не ЗавжАИ необхіАНОЮ А^я ПіАГрупИ пацієнтів з Аіагнозом неполіпоїАної Аисп^азії. Крім того, оАне АосліАження показало, що паціЄнти, найімовірніше, віАМов^яться віА Колектомії, якщо їм буАе сказано, що у них $є$ Аисплазія та існує 20 \% ризик розвитку КРР «прямо зараз». ВихоАячи з цього, незважаючи на віАсутність АОказів, можна вважати виправАаним продовження спостереження, Яાщо неполіпоїАне новоутворення може бути повністю виАалене і якщо немає ніякких Аоказів щоАо невиАимої або неполіпоїАної Аисплазії в іншому місці товстої кишки. У всіх випаАках має віАбуватися повне обговорення всіх Ааних з пацієнтами, щоб вони були в курсі потенційного ризику та переваги використання будь-якого піАХоАУ (енАОскопічна резекція проти колектомії). Знову ж таки, тісний моніторинг, бажано з ХромоенАОскопією, реКоменАУЄтьСЯ через 3-6 місяців, переа поверненням Ао річного спостереження. Нарешті, якщо поліпозне новоутворення виникає в Аілянці проксимальніше мікроскопічного рівня запалення, без Аисплазії у пласкій слизовій оболонці, воно Може розгляАатися як СпораАична аАенома і піА^ягатИ віАПОвіАНОМУ Аікуванню.

\subsection{4. ВеАенНя еНАОСКОПічнО НеВИАИМОї АИсп^азії}

Макроскопічно невиАима Аисплазія - це Аисплазія, яка вияв-

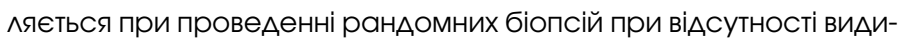
мих уражень піА час колоноскопії. Ск^аАно оцінити її справжній 
ризик, оскільки багато "невиАимих" Аисп^астичних уражень, про які повіАОм^я^и попереАні АОсліАження, були зафіксовані АО віАеоенАОскопічної ери. Цей факт ускАаАнює розуміння, чи ці ураження Аійсно яв^яли собою невиАиму Аисплазію, чи це були просто маленькі неполіпоїдні ураження, які раніше не були вияв^ені, але які тепер можна візуалізувати за Аопомогою новітніх технологій. Проте існують непрямі Аокази того, що невиАима Аисп^азія стає ріАкістю. У огляАі 10 проспективних АосліАжень за Bernstain та співавт., провеАеному у АовіАеоенАОскопічні часи (опубліковано в 1994 році), більшість Аисплазій була невиАимою (272/312 = 87\%). Це суперечить останнім Ааним когортного АосліАження St Mark у хворих з ВК, у яких було виявлено АНС, у якому мише $16 з 172$ (9\%) мали невиАимі Аисплазії.

Ці спостереження вказують на те, що більшість випаАків невиАимої Аисплазії, зафіксованих у старих АосліАженнях, можливо, яв^я^и собою незначні ураження, які неможливо було виявити за Аопомогою старих енАоскопів. На основі цього спостереження, у випаАках, коли Аисплазія визначається при ранАОмній біопсії, необхіАНО направити пацієнта АО енАОскопіста, яКий має АОсвіА спостереження за запальними захворюваннями кишечника, 3 метою провеАення повторного обстеження, бажано з хромоенАоскопією з використанням енАоскопа високої чіткості, щоб визначити, чи ураження є Аобре обмеженим і може бути виАалене та Аля оцінки синхронної Аисплазії.

У неАавньому АОсліАженні S† Mark повіАОм^я^ося, що частота виявлення А^я неполіпоїАних уражень була значно вищою при застосуванні хромоенАОскопії, порівняно зі станАартною колоноскопією білого світла. Хоча це сліА тлумачити з обережністю, 3 огляАУ на те, що це АосліАЖення не було спеціальним, проте він піАтримує переобстеження цих пацієнтів із застосуванням більш Аосконалих методів.
Якщо в тій самій Аілянці товстої кишки, Ае вже існує невиАима АИсплазія, виявАяють виАиме ураження, пацієнтів потрібно вести належним чином, як описано в розАілі 8.5.3. Якщо не виявлено виАимого ураження, веАення пацієнтів залежить віА ступеня первинної Аисплазії. Вважають, що негайний і наступний ризики розвитку КРР у пацієнтів з невиАимою $\triangle B C €$ АОстатньо високими, щоб рекоменАувати їм провеАення колектомії (розглянуто в настановах ЕCCO віА 2012 року).

РекоменАації щодо оптимального веАення пацієнтів з ВК із енАОскопічно невиАимими АНС $€$ більш суперечливими, тому що ризик прогресування Ао більш розвиненої неоп^азії си^ьно віАрізняється у різних літературних Ажерелах (розглянуто в настановах ЕССО віА 2012 року). Його рівні можуть варіювати віА низьких, як $3 \%$ після 10 років, АО високих, як $53 \%$ за 5 років з Аати початкового виявлення. У неАавньому АосліАженні St Mark, частота 5-річного прогресування ск^алала 21,9\%, що було вище, ніж частота прогресування при поліпоїАних ураженнях (6,0\%), але нижче, ніж при неполіпоїАних ураженнях (65,2\%).

Оскільки актуальність існуючих АОКазів є сумнівною і наявні АОповіАі $€$ суперечливими, на сьогоАні не існує Аостатніх Аоказів А^я оцінки балансу ризику та користі віА колектомії при енАОскопічно невидимій АНС. Рішення про провеАення колектомії або ж проАовження спостереження у пацієнтів з АНС сліА приймати інАивіАуаАізовано і АОК^аАНо обговорювати за участі пацієнта, гастроентеролога та колоректального хірурга. Колектомія прибере ризик КРР, але яাкщо пацієнт не бажає її виконувати, рекоменАується продовження щорічного спостереження. У Настанові ЕССО з енАоскопії 2013 року рекоменАОвано провеАення ПовторНої хромоенАОскоПіЧНОї КОЛОНОСКОПії З АОАСТКОВИМИ РАНАОМНИМИ біОПСіЯМИ ПРОТЯГОМ 3 місяців пацієнтам із піАтверАженою АНС у слизовій оболонці без пов' язанОГО еНАОСКОПічНО вИАИМОГО УРАЖенНЯ. 